\title{
Modifications of Saccharomyces pastorianus cell wall polysaccharides with brewing process
}

Rita Bastos, Elisabete Coelho*, Manuel A. Coimbra

QOPNA. Departamento de Química, Universidade de Aveiro, 3810-193 Aveiro, Portugal

*Corresponding author. Tel +351 234370 706; fax: +351234370 084

Email address: ecoelho@ua.pt (Elisabete Coelho)

\section{ABSTRACT}

2 The cell wall polysaccharides of brewers spent yeast Saccharomyces pastorianus (BSY)

3 and the inoculum yeast (IY) were studied in order to understand the changes induced by

4 the brewing process. The hot water and alkali extractions performed solubilized mainly

5 mannoproteins, more branched for BSY than those of IY. Also, ${ }^{31} \mathrm{P}$ solid state NMR

6 showed that the BSY mannoproteins were 3 times more phosphorylated. By electron

7 microscopy it was observed that the final residues of alkali sequential extraction until 4

$8 \mathrm{M} \mathrm{KOH}$ preserved the yeast three-dimensional structure. The final residues, composed

9 mainly by glucans (92\%), showed that the BSY, when compared with IY, contained higher amount of $(1 \rightarrow 4)$-linked Glc ( $43 \%$ for BSY and $16 \%$ for IY) and lower $(1 \rightarrow 3)$ linked Glc (17\% for BSY and $42 \%$ for IY). The enzymatic treatment of final residue showed that both BSY and IY had $(\alpha 1 \rightarrow 4)$-linked Glc and $(\beta 1 \rightarrow 4)$-linked Glc, in a 2:1 ratio, showing that $S$. pastorianus increases their cellulose-like linkages with the brewing process.

Keywords: brewers spent yeast; sequential extraction; mannoprotein; glucan; alcoholic fermentation stress. 


\section{Introduction}

Mannoproteins and $\beta$-glucans represent the majority of the compounds of Saccharomyces brewing cell walls used as brewing yeasts. However, as they are highly entangled in the cell wall matrix, they are difficult to extract (Liu, Wang, Cui \& Liu, 2008; Quirós, Morales, Pérez-Través, Barcenilla \& Gonzalez, 2011), mainly the $\beta$ glucans, preventing their structural characterization (Pinto, Coelho, Nunes, Brandão \& Coimbra, 2015).

Cell wall mannoproteins could be $N$-linked if carbohydrate moieties are linked to the nitrogen of asparagine or arginine, or $O$-linked if mannans have a glycosidic linkage to the hydroxyl oxygen of serine or threonine. $N$-linked mannoproteins can be extended with an outer chain of 50-200 $(\alpha 1 \rightarrow 6)$ linked Man residues extensively branched with short $(\alpha 1 \rightarrow 2)$-Man side chains with terminal $(\alpha 1 \rightarrow 3)$-Man residues. $N$-linked type mannoproteins are the majority of yeast mannoproteins and are essentially composed by $90 \%$ carbohydrate and $10 \%$ protein, having a relevant structural function (Lesage \& Bussey, 2006). These $N$-linked mannans can contain phosphate groups as mannosylphosphate residues that contribute for the ionic properties of yeast cell surface (Jigami \& Odani, 1999). The $O$-linked mannoproteins are composed by $50 \%$ of protein and $50 \%$ of carbohydrates, bearing oligosaccharide chains containing 1 to $5(\alpha 1 \rightarrow 2)$ Man and $(\alpha 1 \rightarrow 3)$-Man units usually with one mannosylphosphate residue (Corbacho, Olivero \& Hernández, 2005). These mannoproteins are responsible for several enzymatic activities (Lesage \& Bussey, 2006).

The yeast cell wall inner layer is composed of glucans mainly constituted by $(\beta 1 \rightarrow 3)$-Glc residues $(85 \%)$ and $(\beta 1 \rightarrow 6)$-Glc residues $(15 \%)$. The outer layer of mannoproteins are covalently attached to these polymers (Klis, Boorsma \& De Groot, 2006). Also, $(\alpha 1 \rightarrow 4)$-Glc residues with $(\alpha 1 \rightarrow 4,6)$-Glc linkages has been identified in Saccharomyces cell walls, covalently linked to $(\beta 1 \rightarrow 6)$-glucans. These polymers were 
identified as insoluble glycogen-like polysaccharides and could represent 1 to $23 \%$ of yeast cell wall dry weight (Arvindekar \& Patil, 2002; Kwiatkowski, Thielen, Glenney \& Moran, 2009).

The existence of $(\beta 1 \rightarrow 4)$-linked glucans in the BSY Saccharomyces pastorianus cell walls has been recently reported, accounting for $30 \%$ of the $(1 \rightarrow 4)$-linked glucans (Pinto et al., 2015). S. pastorianus is an allotetraploid hybrid yeast derived from $S$. cerevisiae and an S.bayanus (Rainieri et al., 2006; Tamai, Momma, Yoshimoto \& Kaneko, 1998). S. pastorianus is a lager brewing strain that, contrary to S. cerevisiae, sinks on fermentation tank because of its more hydrophilic surface (Dengis, Nelissen \& Rouxhet, 1995).

In order to evaluate the modifications of $S$. pastorianus cell wall polysaccharides with brewing process, the yeast of inoculum (IY) and the BSY were studied. For that, a sequential extraction of yeast polysaccharides was performed. Yeast intracellular material was released by sonication and yeast cell walls were prepared as alcohol insoluble residues (AIRs), and then subjected to sequential extraction with alkali solutions. Sugars and methylation analysis were performed. Also, the differences in mannoprotein phosphorylation were evaluated by ${ }^{31} \mathrm{P}$ solid state NMR and the glucans that remained in the insoluble residues were enzymatically treated with $\alpha$-amylase and cellulase to determine the anomeric configuration of the $(1 \rightarrow 4)$-Glc linkages.

\section{Materials and methods}

\subsection{Samples}

Inoculum yeast (IY) and brewers spent yeast (BSY) were provide by Unicer Bebidas SA., Portugal. IY was collected from the $4^{\text {th }}$ generation of yeasts adapted to the fermentation broth, and BSY was collected from the bottom of fermentation reactor after 3-7 fermentative cycles. 


\subsection{Sequential extraction of yeast polysaccharides}

An aqueous suspension of yeast cells (IY and BSY) were submitted to 15 min of sonication, and the solubilized material was separated from the insoluble residue by centrifugation at $4^{\circ} \mathrm{C}$ and $24,652 g$ during $20 \mathrm{~min}$. The soluble fractions were precipitated with $80 \%(\mathrm{v} / \mathrm{v})$ ethanol at $4^{\circ} \mathrm{C}$ during $2 \mathrm{~h}$. The yeast cells residues were boiled with $80 \%(\mathrm{v} / \mathrm{v})$ ethanol during $10 \mathrm{~min}$ in order to prepare the alcohol insoluble residues (AIR). Each AIR was submitted to a hot water extraction during $15 \mathrm{~min}$ at $100^{\circ} \mathrm{C}$ with an $\mathrm{AIR} /$ water ratio of $1: 16(\mathrm{w} / \mathrm{v})$. The residue left was submitted to an alkali extraction with $0.1 \mathrm{M} \mathrm{KOH}+20 \mathrm{mM} \mathrm{NaBH}_{4}$ using oxygen-free solutions to prevent peeling reactions. The alkali extraction was performed at room temperature during $2 \mathrm{~h}$ with continuous stirring, and the insoluble material was separated from the soluble one by centrifugation. The extracted material was acidified to $\mathrm{pH} 5$ and then dialyzed against water with $12-14 \mathrm{kDa}$ molecular weight cut off membranes. After dialysis, the precipitated extracted material with $0.1 \mathrm{M} \mathrm{KOH}$ was separated by centrifugation at $24,652 g, 4^{\circ} \mathrm{C}$ during $20 \mathrm{~min}$. The sequential extraction proceeded with $1 \mathrm{M}$ and $4 \mathrm{M}$ $\mathrm{KOH}$ solutions using the same procedure described above. The residue left after $4 \mathrm{M}$ $\mathrm{KOH}$ extraction was suspended in $200 \mathrm{~mL}$ of water, neutralized to $\mathrm{pH} 5$ with glacial acetic acid, dialyzed, and centrifuged, allowing to obtain the final residue (FR) and a material that remained soluble inside the dialysis membrane (snFR) (Fig.1). Each supernatant, precipitate, and the FR collected were suspended in water, concentrated by rotary evaporation under reduced pressure, frozen, and freeze-dried. 


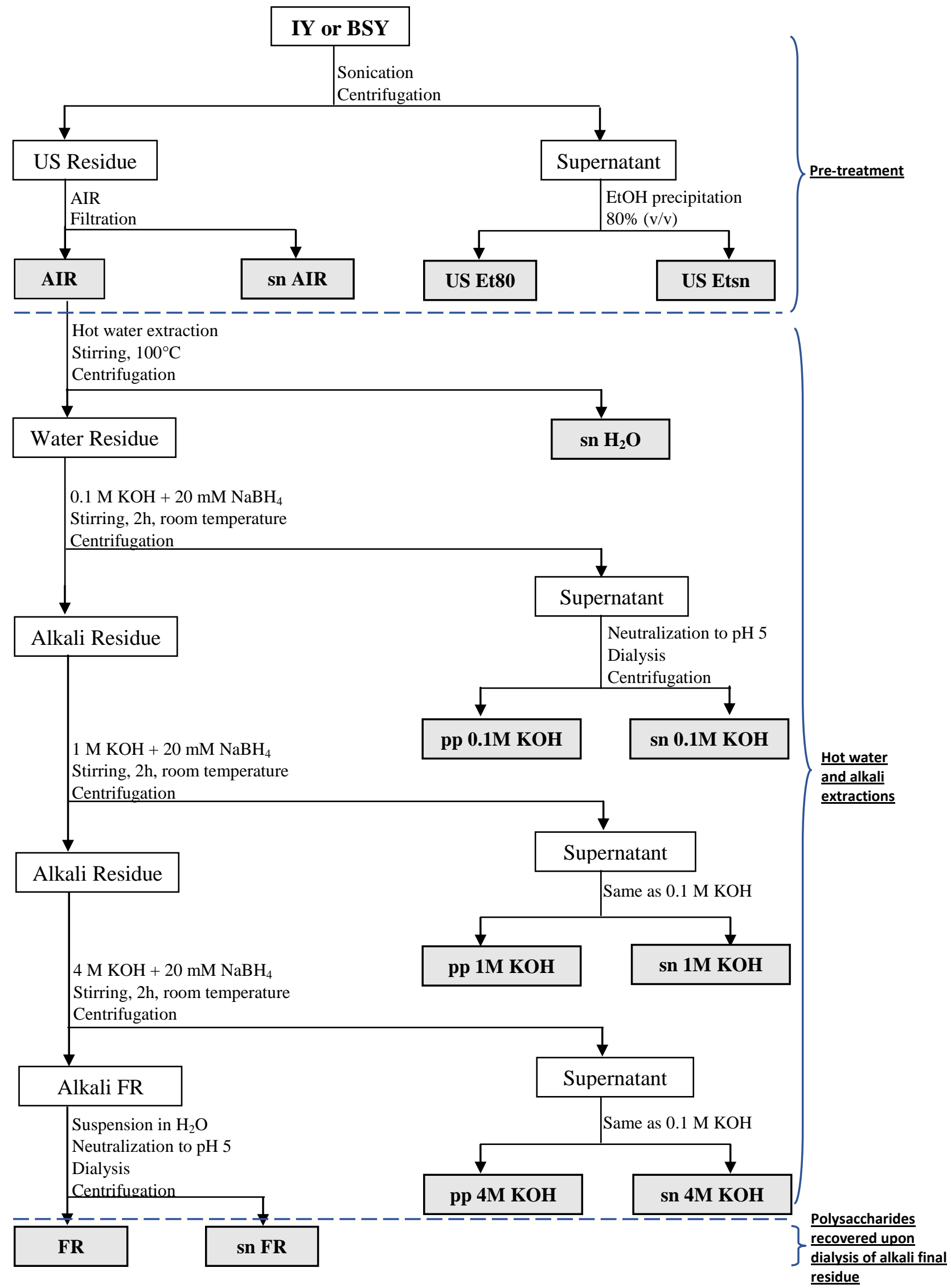

Fig. 1: Schematic representation of sequential extraction of inoculum yeast (IY) and brewers spent yeast (BSY). 


\subsection{Sugar analysis}

The sugars composition of the polysaccharides were determined by gas chromatography-flame ionization detection (GC-FID) as alditol acetates and quantified using 2-deoxyglucose as internal standard (Blakeney, Harris, Henry \& Stone, 1983). Monosaccharides were released from polysaccharides (1-2 mg of sample) by prehydrolysis in $0.2 \mathrm{~mL}$ of $72 \% \mathrm{H}_{2} \mathrm{SO}_{4}(\mathrm{w} / \mathrm{w})$ for $3 \mathrm{~h}$ at room temperature followed by 2.5 h hydrolysis in $1 \mathrm{M} \mathrm{H}_{2} \mathrm{SO}_{4}$ at $100^{\circ} \mathrm{C}$ (Selvendran, March \& Ring, 1979). After $1 \mathrm{~h}$ hydrolysis, it was collected $0.5 \mathrm{~mL}$ of solution for uronic acids determination. Monosaccharides were reduced with $\mathrm{NaBH}_{4}\left(15 \%\right.$ in $\left.3 \mathrm{M} \mathrm{NH}_{3}\right)$ during $1 \mathrm{~h}$ at $30{ }^{\circ} \mathrm{C}$ and then acetylated, with acetic anhydride $(3 \mathrm{~mL})$ and 1-methylimidazole $(450 \mu \mathrm{L})$, during $30 \mathrm{~min}$ at $30{ }^{\circ} \mathrm{C}$. The alditol acetates were separated by liquid-liquid extraction with water and dichloromethane and after evaporation of organic solvent, were solubilized in anhydrous acetone and analysed by a GC-FID Perkin Elmer-Clarus 400 with a capillary column DB-225 (30 m length, $0.25 \mathrm{~mm}$ inner diameter and $0.15 \mu \mathrm{m}$ film thickness). The oven temperature program was as follows: $200{ }^{\circ} \mathrm{C}$ to $220{ }^{\circ} \mathrm{C}$ at a rate of $40{ }^{\circ} \mathrm{C} / \mathrm{min}$ (7 min), increasing to $230^{\circ} \mathrm{C}$ at a rate of $20^{\circ} \mathrm{C} / \mathrm{min}(1 \mathrm{~min})$. The temperature of injector was $220{ }^{\circ} \mathrm{C}$ and the detector was $230{ }^{\circ} \mathrm{C}$. Hydrogen was used as carrier gas at a flow rate of $1.7 \mathrm{~mL} / \mathrm{min}$.

Uronic acid content was determined by the $m$-phenylphenol colorimetric method (Blumenkrantz \& Asboe-Hansen, 1973) using galacturonic acid as standard. To the 0.5 $\mathrm{mL}$ of diluted hydrolysed sample (1:4) was added $3 \mathrm{~mL}$ of boric acid $50 \mathrm{mM} \mathrm{H} \mathrm{SO}_{4}$ $98 \%$ (w/w), after shaken the test tubes were heated at $100{ }^{\circ} \mathrm{C}$ during $10 \mathrm{~min}$. After cooling, $100 \mu \mathrm{L}$ of $m$-phenylphenol was added, reacting $30 \mathrm{~min}$ in dark, and the absorbance was measured at $520 \mathrm{~nm}$. 


\subsection{Glycosidic-linkage analysis}

117

118

119

120

121

122

123

124

125

126

127

The glycosidic-linkage composition was determined by gas chromatographyquadrupole mass spectrometry (GC-qMS) of partially methylated alditol acetates (Ciucanu \& Kerek, 1984; Nunes \& Coimbra, 2002). The samples (1-2 mg) were dissolved in $1 \mathrm{~mL}$ of anhydrous dimethylsulfoxide (DMSO), and then powdered $\mathrm{NaOH}$ (40 mg) were added under an argon atmosphere. The samples were methylated with $\mathrm{CH}_{3} \mathrm{I}(80 \mu \mathrm{L})$ during 20 min with stirring, following by a second addition of $80 \mu \mathrm{L}$ $\mathrm{CH}_{3} \mathrm{I}$ and stirring for another $20 \mathrm{~min} . \mathrm{CHCl}_{3} / \mathrm{CH}_{3} \mathrm{OH}(1: 1$, v/v, $3 \mathrm{~mL})$ was added, and the solution was dialyzed (membrane with a pore diameter of 12-14 kDa) against 3 lots of $50 \%$ ethanol. The dialysate was evaporated to dryness and the material was remethylated using the same procedure. The remethylated material was hydrolysed with $2 \mathrm{M}$ TFA $(500 \mu \mathrm{L})$ at $120^{\circ} \mathrm{C}$ for $1 \mathrm{~h}$, and then reduced and acetylated as previously described for sugar analysis, using $\mathrm{NaBD}_{4}$ instead of $\mathrm{NaBH}_{4}$. The partially methylated alditol acetates were separated and analysed by GC-qMS using an Agilent Technologies 6890N Network. The GC was equipped with a DB-1 (J\&W Scientific, Folsom, CA, USA) capillary column (30 m length, $0.25 \mathrm{~mm}$ of internal diameter, and $0.15 \mu \mathrm{m}$ of film thickness). The samples were injected in "split" mode during 5 min using an injector temperature of $220^{\circ} \mathrm{C}$, during $5 \mathrm{~min}$. The temperature program used was as follows: initial temperature was $50^{\circ} \mathrm{C}$, with a linear increase of $8^{\circ} \mathrm{C} / \mathrm{min}$ until $140^{\circ} \mathrm{C}(5 \mathrm{~min})$, followed by a linear increase of $0.5^{\circ} \mathrm{C} / \mathrm{min}$ until $150^{\circ} \mathrm{C}$ followed by a linear increase of $40^{\circ} \mathrm{C} / \mathrm{min}$ until $250^{\circ} \mathrm{C}(1 \mathrm{~min})$. The helium carrier gas had a flow rate of $1.7 \mathrm{~mL} / \mathrm{min}$ and a column head pressure of 14.4 psi. The GC was connected to an Agilent 5973 mass quadrupole selective detector operating with an electron impact mode at $70 \mathrm{eV}$ and scanning the range $m / z 40-500,1 \mathrm{~s}$ cycle, in a full scan mode acquisition. 
The FR samples were treated with $\alpha$-amylase and cellulase as described for Pinto et al. (2015). The hydrolysis of $(\alpha 1 \rightarrow 4)$-Glc linkages were performed with a $62 \mathrm{U} / \mathrm{mg} \alpha$ amylase from Bacillus subtilis (Sigma-Aldrich, EC 3.2.1.1) on $10 \mathrm{mg}$ of sample, suspended in $5 \mathrm{~mL}$ of $50 \mathrm{mM}$ phosphate buffer $\mathrm{pH} 7.0$, during $2 \mathrm{~h}$ at $25{ }^{\circ} \mathrm{C}$ with continuous stirring. The hydrolysis of $(\beta 1 \rightarrow 4)$-Glc linkages was held with a $1.5 \mathrm{U} / \mathrm{mg}$ cellulase from Aspergillus niger (Sigma-Aldrich, EC 3.2.1.4) and $10 \mathrm{mg}$ of sample, suspended in $5 \mathrm{~mL}$ of $20 \mathrm{mM}$ acetate buffer $\mathrm{pH} 5.0$, during $4 \mathrm{~h}$ at $37{ }^{\circ} \mathrm{C}$, with continuous stirring. The enzymatic reactions were stopped by boiling for $10 \mathrm{~min}$, and samples were dialyzed, frozen and then freeze-dried. 


\section{Results and discussion}

165

166

167

168

169

170

composed by $70 \mathrm{~mol} \%$ of glucose and 19 mol\% of mannose (Table 1).

171

172

treatment of IY and BSY with ultrasounds in order to increment the release of the

intracellular material and preparation of an AIR of cell walls, with further hot water,

177

0.1, 1.0 and 4.0 M KOH alkali extractions. The mass yields and sugars composition of the extracts and final residues of IY and BSY extractions are shown in Table 1 and the

179 glycosidic linkages composition are shown in Table 2.

180 Table 1: Extraction yields and carbohydrate composition of the fractions obtained by sequential extraction of IY and BSY.

\begin{tabular}{|c|c|c|c|c|c|c|c|c|c|c|c|c|}
\hline \multirow[t]{2}{*}{ Fraction } & \multirow{2}{*}{$\begin{array}{l}\text { Yield (\%) } \\
(w / w)\end{array}$} & \multirow{2}{*}{$\begin{array}{l}\text { Yield }(\%) * \text { in } \\
\text { extracted } \\
\text { carbohydrates }\end{array}$} & \multicolumn{9}{|c|}{ Carbohydrates (mol\%) } & \multirow{2}{*}{$\begin{array}{c}\text { Total } \\
\text { carbohydrate } \\
(\mu \mathrm{g} / \mathrm{mg})\end{array}$} \\
\hline & & & dRib & Rha & Rib & Ara & Xyl & Man & Gal & Glc & HexA & \\
\hline IY & - & - & 1 & - & 2 & 1 & 1 & 33 & - & 60 & 1 & 555 \\
\hline US Et80 & 10.2 & 11.7 & 1 & - & 1 & 3 & 4 & 15 & 1 & 74 & 2 & 635 \\
\hline US EtSn & 9.9 & 4.8 & 1 & - & 0 & 3 & 4 & 2 & - & 88 & 3 & 267 \\
\hline sn AIR & 5.6 & 1.1 & 5 & 1 & 2 & 1 & 3 & 2 & - & 81 & 4 & 110 \\
\hline AIR & 59.3 & 40.7 & 1 & - & 6 & - & - & 45 & - & 45 & 2 & 381 \\
\hline sn $\mathrm{H}_{2} \mathrm{O}_{100^{\circ} \mathrm{C}}$ & $4.1(6.9)$ & $2.8(6.8)$ & 2 & - & 13 & 1 & 1 & 50 & - & 30 & 2 & 374 \\
\hline sn $0.1 \mathrm{M} \mathrm{KOH}$ & $2.3(3.9)$ & $2.0(5.0)$ & 2 & - & 20 & 1 & 1 & 67 & - & 5 & 3 & 487 \\
\hline pp $0.1 \mathrm{M} \mathrm{KOH}$ & $3.1(5.2)$ & $0.6(1.5)$ & 5 & - & 70 & - & - & 18 & - & 3 & 3 & 111 \\
\hline sn $1 \mathrm{M} \mathrm{KOH}$ & $1.3(2.1)$ & $1.1(2.8)$ & 1 & - & 1 & 2 & 2 & 81 & - & 10 & 2 & 500 \\
\hline pp $1 \mathrm{M} \mathrm{KOH}$ & $1.9(3.2)$ & $0.3(0.6)$ & 12 & - & 1 & 4 & 2 & 26 & - & 51 & 3 & 74 \\
\hline sn $4 \mathrm{M} \mathrm{KOH}$ & $2.9(4.9)$ & $3.7(9.2)$ & 1 & - & 1 & 1 & 2 & 83 & - & 9 & 4 & 712 \\
\hline pp 4M KOH & $2.4(4.0)$ & $0.8(2.1)$ & 4 & - & - & 1 & 1 & 8 & - & 82 & 3 & 197 \\
\hline sn FR & $1.8(3.0)$ & $2.3(5.7)$ & - & - & - & - & - & 66 & - & 30 & 3 & 726 \\
\hline FR & $17.2(29.1)$ & $15.9(39.0)$ & - & - & - & - & - & 6 & - & 91 & 2 & 511 \\
\hline BSY & - & - & 2 & - & 2 & 1 & 1 & 19 & - & 70 & 5 & 469 \\
\hline
\end{tabular}




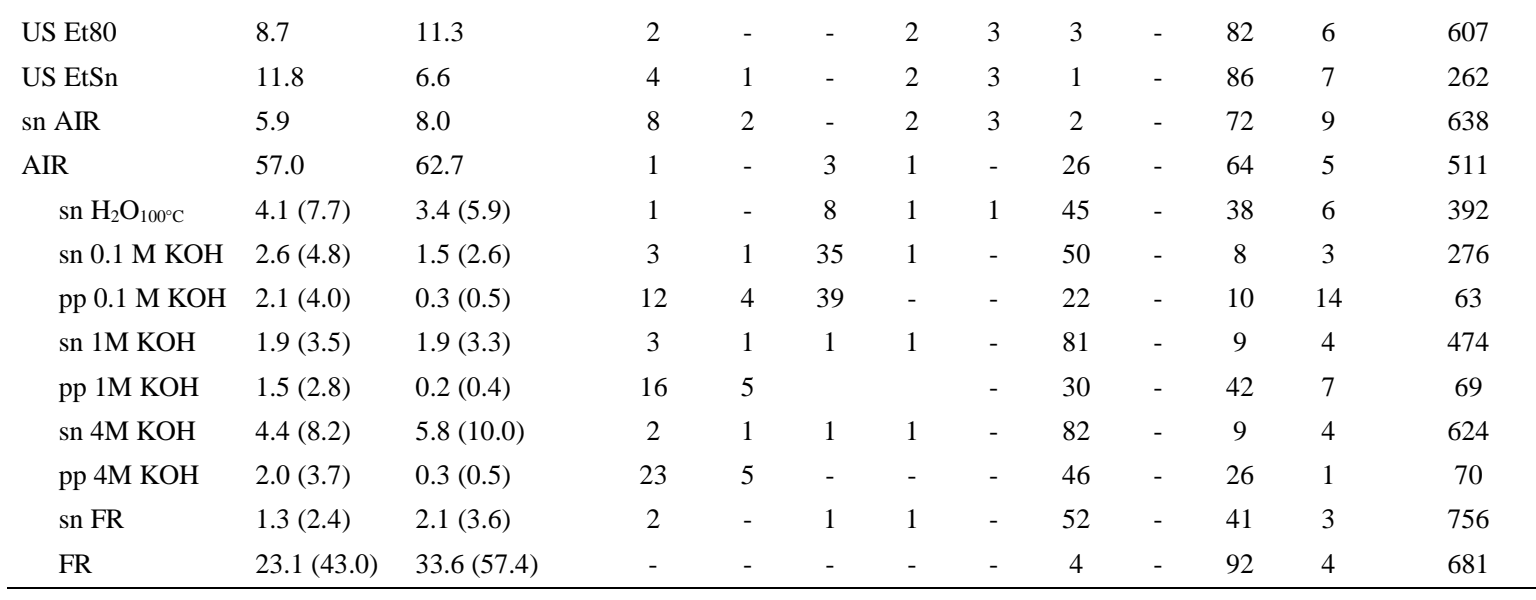

Values between brackets correspond to yields calculated in AIR mass basis. * The yield of extracted carbohydrates was calculated considering the concentration of carbohydrates (total of carbohydrates in $\mathrm{mg} / \mathrm{g}$ ) and the mass $(\mathrm{g}$ ) of respective fraction. With these carbohydrates mass values it was possible to calculate the yield of carbohydrates extracted in initial yeast or AIR basis.

\subsubsection{Yeasts pre-treatment}

The pre-treatment of yeasts with sonication solubilised $17 \%$ of IY carbohydrates and $18 \%$ of BSY (sum of yields of US EtSn and US Et80). The extracted material that precipitated with ethanol was mainly composed of glucose, namely $74 \mathrm{~mol} \%$ for IY and $82 \mathrm{~mol} \%$ for BSY. Glycosidic-linkage analysis of US Et80 showed that glucose was mainly $(1 \rightarrow 4)$-Glc $(44.4 \mathrm{~mol} \%$ for IY and $56.3 \mathrm{~mol} \%$ for BSY $)$ and $(1 \rightarrow 4,6)$-Glc $(10.5$ mol\% for IY and 16.7 mol\% for BSY), which are probably the linkages of intracellular glycogen. The ultrasounds treatment allowed the extraction of intracellular glycogen probably through the increasing permeability and disruption of the cell wall (Liu, Zeng, Sun \& Han, 2013; Zhang, Jin, Xie, Wu \& Wu, 2014).

From the residues of yeasts ultrasonic treatment, it was prepared the AIR of both yeasts cell walls. The AIR of IY represented 59\% of initial yeast dry weight and 57\% for BSY, with a yield of carbohydrates higher for BSY than IY AIR, 63\% and 41\%, respectively. Also, the BSY AIR was richer in carbohydrates (51\%) than IY AIR (38\%) and with a higher proportion of glucose $(64 \mathrm{~mol} \%)$. The glycosidic linkage analysis shows that the BSY AIR glucose was mainly $(1 \rightarrow 4)$-Glc $(38$ mol\%), 4 times higher than that present in IY AIR, indicating a possible higher proportion of $(1 \rightarrow 4)$-Glc in the 
203 BSY cell walls. In AIR yeast cell walls was also present $(1 \rightarrow 3)$-Glc $(10.8 \mathrm{~mol} \%$ for IY 204 and $6.7 \mathrm{~mol} \%$ for BSY) and $(1 \rightarrow 6)$-Glc $(3.1 \mathrm{~mol} \%$ for IY and $5.8 \mathrm{~mol} \%$ for BSY), 205 possibly constituents of $\beta$-glucans (Klis, Mol, Hellingwerf \& Brul, 2002). Both yeasts 206 had similar proportions of $(1 \rightarrow 2)$-Man $(10.1 \mathrm{~mol} \%$ for IY and $5.8 \mathrm{~mol} \%$ for BSY $)$ and $207(1 \rightarrow 2,6)$-Man linkages $(11.6 \mathrm{~mol} \%$ for IY and $9.4 \mathrm{~mol} \%$ for BSY), showing that the 208 mannoproteins of IY and BSY AIR are highly branched.

209 
Table 2: Glycosidic-linkage composition (mol\%) of IY and BSY fractions of sequential extraction.

\begin{tabular}{|c|c|c|c|c|c|c|c|c|c|c|c|c|}
\hline \multirow{2}{*}{$\begin{array}{l}\text { Glycosidic } \\
\text { linkages }\end{array}$} & \multicolumn{6}{|l|}{ IY } & \multicolumn{6}{|l|}{ BSY } \\
\hline & US Et80 & AIR & $\begin{array}{l}\text { sn } \mathrm{H}_{2} \mathrm{O} \\
100^{\circ} \mathrm{C}\end{array}$ & $\begin{array}{l}\text { sn 4M } \\
\text { KOH }\end{array}$ & sn FR & FR & US Et80 & AIR & $\begin{array}{l}\text { Sn } \mathrm{H}_{2} \mathrm{O} \\
100^{\circ} \mathrm{C}\end{array}$ & $\begin{array}{l}\text { sn 4M } \\
\text { KOH }\end{array}$ & sn FR & FR \\
\hline $\mathrm{t}$-Ara & 5.2 & 0.4 & $\mathrm{t}$ & - & - & - & 2.1 & 0.6 & - & 0.1 & - & - \\
\hline Total & $5.2(4)$ & $0.4(0)$ & $\mathbf{t}(\mathbf{1})$ & - & - & - & $2.1(2)$ & $0.6(1)$ & - & $0.1(1)$ & - & - \\
\hline 4-Xyl & 3.3 & 0.5 & $\mathrm{t}$ & - & - & - & 2.1 & 1.5 & 6.1 & 0.3 & - & - \\
\hline Total & $3.3(3)$ & $0.5(0)$ & $\mathbf{t}(1)$ & - & - & - & $2.1(3)$ & $1.5(0)$ & $6.1(1)$ & $0.3(0.3)$ & - & - \\
\hline t-Man & 6.5 & 13.5 & 13.0 & 39.0 & 23.3 & 3.6 & 0.4 & 8.7 & 15.1 & 29.6 & 21.1 & 2.4 \\
\hline 2-Man & 3.3 & 10.1 & 13.5 & 19.0 & 14.6 & 3.9 & 0.2 & 5.8 & 10.8 & 20.0 & 13.1 & 1.2 \\
\hline 3-Man & - & 4.0 & $\mathrm{t}$ & 10.1 & 8.2 & - & - & - & $\mathrm{t}$ & 7.4 & 4.3 & - \\
\hline 4-Man & - & 0.4 & - & $\mathrm{t}$ & 0.3 & - & - & - & 0.9 & 0.4 & 0.5 & - \\
\hline 6-Man & 0.4 & 1.3 & 1.2 & 1.8 & 1.3 & 1.0 & 0.4 & 1.2 & 1.1 & 2.2 & 1.2 & $\mathrm{t}$ \\
\hline 2,6-Man & 3.9 & 11.6 & 10.4 & 13.1 & 22.1 & 3.5 & 2.1 & 9.4 & 12.6 & 29.5 & 13.4 & 2.5 \\
\hline 3,6-Man & - & 1.3 & $\mathrm{t}$ & 1.2 & 0.5 & - & - & 0.8 & 1.0 & 0.7 & - & - \\
\hline $\begin{array}{l}2,3,6 / 2,4,6- \\
\text { Man }\end{array}$ & - & - & - & 0.5 & 0.7 & - & - & - & - & 0.6 & 0.6 & - \\
\hline 2,3,4,6-Man & 3.0 & 14.3 & 13.8 & 0.4 & 0.5 & 0.3 & 0.1 & 1.5 & 2.2 & 0.4 & 1.3 & 0.9 \\
\hline Total & $17.1(15)$ & $56.5(45)$ & $54.1(50)$ & $85.1(83)$ & $71.5(65)$ & $12.3(6)$ & $3.1(3)$ & 28.0 & $43.6(45)$ & $90.7(82)$ & $55.6(52)$ & $7.0(4)$ \\
\hline $\mathrm{t}-\mathrm{Glc}$ & 15.5 & 2.8 & 5.3 & 1.3 & 2.6 & 8.6 & 16.9 & 6.9 & 4.9 & 0.5 & 5.4 & 10.0 \\
\hline 3-Glc & 0.2 & 10.8 & 1.4 & 1.4 & 0.5 & 41.8 & 1.0 & 6.7 & 1.7 & 0.2 & 0.8 & 17.3 \\
\hline 4-Glc & 44.4 & 9.3 & 27.3 & 8.0 & 21.1 & 15.9 & 56.3 & 38.0 & 30.3 & 6.6 & 27.1 & 42.7 \\
\hline 6-Glc & 0.7 & 3.1 & 2.3 & 0.7 & 0.4 & 11.3 & 1.5 & 5.8 & 1.9 & 0.6 & 1.2 & 9.3 \\
\hline 2,3-Glc & - & 0.9 & - & - & - & 0.7 & - & 0.8 & $\mathrm{t}$ & - & - & 1 \\
\hline 3,4-Glc & - & 0.4 & - & - & - & 0.2 & - & 0.5 & $\mathrm{t}$ & - & - & 0.4 \\
\hline 3,6-Glc & - & 1.2 & - & - & - & 3.3 & - & 1.0 & $\mathrm{t}$ & - & - & 2.2 \\
\hline 4,6-Glc & 10.5 & 1.4 & 5.0 & 0.8 & 2.3 & 1.2 & 16.7 & 3.8 & 3.5 & - & 1.7 & 5.4 \\
\hline 2,3,4,6-Glc & 3.19 & 11.3 & 6.9 & 1.5 & 1.2 & 3.4 & 0.2 & 4.6 & 5.5 & 0.8 & 6.6 & 3.7 \\
\hline Total & $74.4(74)$ & $41.2(45)$ & $46.0(30)$ & $13.7(9)$ & $28.2(30)$ & 86.4 (89) & $92.6(82)$ & $\begin{array}{l}68.2 \\
(64)\end{array}$ & $47.7(38)$ & $8.7(9)$ & $42.9(41)$ & $92.0(90)$ \\
\hline 4-GlcNAc & - & 0.8 & - & 0.9 & 0.1 & 1.1 & - & 1.5 & 1.3 & 0.1 & 0.6 & 0.5 \\
\hline Total & - & 0.8 (n.d.) & - & 0.9 (n.d.) & 0.1 (n.d.) & 1.1 (n.d.) & - & 1.5 (n.d.) & 1.3 (n.d.) & 0.1 (n.d.) & 0.6 (n.d.) & 0.5 (n.d.) \\
\hline
\end{tabular}

Values between brackets correspond to data from sugar analysis. $\mathrm{t}=$ trace; $\mathrm{n} . \mathrm{d} .=$ not determined in sugar analysis.

\subsubsection{Hot water and alkali polysaccharides extraction}


releasing of the intracellular material led to recover a fraction with higher recovery of mannose, consistent with extraction of cell wall mannoproteins. The mannose residues were mainly $(1 \rightarrow 2)$-Man and $(1 \rightarrow 2,6)$-Man residues, present in similar proportions for both yeasts. The glucose solubilised in hot water had the characteristic glycosidic linkages of glycogen, namely $(1 \rightarrow 4)$-Glc $(27 \mathrm{~mol} \%$ for IY and $30 \mathrm{~mol} \%$ for BSY) and $(1 \rightarrow 4,6)-$ Glc $(5 \mathrm{~mol} \%$ for IY and $3.5 \mathrm{~mol} \%$ for BSY).

The sequential alkali extraction with $0.1 \mathrm{M} \mathrm{KOH}$ allowed the solubilization of $6.5 \%$ and $3.1 \%$ of AIR carbohydrates from IY and BSY, respectively (sum of yields of sn and pp fractions). These fractions were poor in carbohydrates and were mainly constituted by ribose, with $70 \mathrm{~mol} \%$ for IY. As the presence of ribose in yeast cell wall is only described to the yeast Ustilago maydis (5\%), (Ruiz-Herrera, Leon, Carabez-Trejo \& Reyes-Salinas, 1996), the extracted ribose probably comes from yeasts' RNA.

The extraction with $1 \mathrm{M} \mathrm{KOH}$ solubilised 2.8 and $3.3 \%$ polysaccharides from IY and BSY AIR, respectively, with about $50 \%$ carbohydrates and $81 \mathrm{~mol} \%$ of mannose residues, attributed to yeast mannoproteins. The alkali extraction with $4 \mathrm{M} \mathrm{KOH}$ led to mol\% of branched mannose for IY could indicate that the $4 \mathrm{M} \mathrm{KOH}$ solution extracted 
$250(1 \rightarrow 2,6)$-Man to the total of mannose residues shows that BSY has 1 branching for each

2516 residues and BSY has 1 branching for each 3 residues. The extraction of higher

252 branched structure in BSY suggests that after brewing process the yeasts exhibit more

253 branched mannoproteins. These higher branched mannoproteins structures could be

254 important to yeast flocculation and protection against fermentative stress (Soares,

255 2011). During environmental brewing stress, it was shown that Saccharomyces

256 pastorianus increase the amount of cell wall mannoproteins, the resistance to lytic

257 enzymes, and the lectin-receptor interactions (Gibson, Lawrence, Leclaire, Powell \&

258 Smart, 2007; Smart, 2009). In turn, flocculation provides protection of yeasts against

259 ethanol stress and prevents the losing of cell viability (Soares, 2011).

260 Another important feature for yeasts survival under stress conditions is the presence

261 of phosphorylated mannoproteins. As the sn4M KOH was the fraction with higher content of mannoproteins extracted, it was performed a ${ }^{31} \mathrm{P}$ solid NMR analysis to investigate the presence of phosphate in these samples. As shown in Fig. 2, the ${ }^{31} \mathrm{P}$ solid NMR analysis reveals one peak between -10 and $10 \mathrm{ppm}$, a range that includes 265 phosphates in phosphodiester linkages (Sang, Prakash \& Seib, 2007). As NMR was performed in same HPDEC conditions for both samples, we can conclude that the sn4M of BSY had 3 times more phosphate than sn4M of IY. This result suggests that mannosylphosphorylation in yeast cell wall have been induced under stress conditions. Mannosylphosphates give a net negative charge to cell wall surface, providing a more hydrophilic and rigid structure to the yeasts and increasing their tolerance against osmotic stress and lytic enzymes (Jigami et al., 1999). 
a)

273
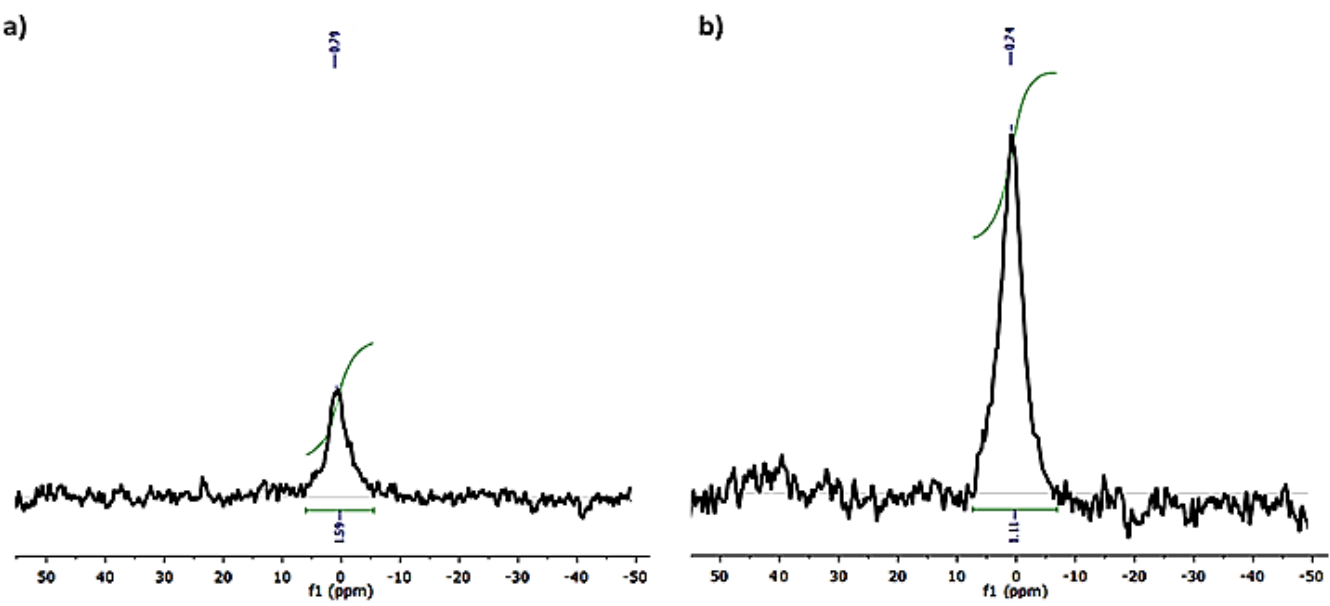

Fig. 2: ${ }^{31} \mathrm{P}$ solid NMR spectra of sn4M from a) IY and b) BSY. Both spectra are at same scale.

\subsubsection{Polysaccharides recovered upon dialysis of alkali final residue}

The material that remained insoluble after the alkali sequential extraction was neutralised, dialyzed and centrifuged, allowing to obtain the material that became soluble in water and retained inside the dialysis membrane (snFR) separated from the insoluble final residue (FR). The snRF fraction had a high carbohydrate recovery $(5.7 \%$ for IY and $3.6 \%$ for BSY) and content of sugars (73 \% for IY and $76 \%$ for BSY). The snRF was mainly composed by mannose (65 mol\% for IY and $52 \mathrm{~mol} \%$ for BSY) and glucose residues (30 mol\% for IY and $41 \mathrm{~mol} \%$ for BSY), which indicates that it was possible, by this separation and recovery of snRF, to obtain a large proportion of remaining mannose and a high content of glucans. After the $4 \mathrm{M} \mathrm{KOH}$ extraction, the recovery of yeast glucans increased, and the higher amount of $(1 \rightarrow 4)$-Glc $(21$ mol\% for IY and $27 \mathrm{~mol} \%$ for BSY) solubilized with $(1 \rightarrow 4,6)$-Glc linkages $(2.3 \mathrm{~mol} \%$ for IY and $1.6 \mathrm{~mol} \%$ for BSY) is in accordance with the presence of glycogen in yeast cell wall, as reported for BSY (Pinto et al., 2015) and S. cerevisiae (Arvindekar et al., 2002).

The FR represents $17 \%$ and $23 \%$ of IY and BSY initial dry weight, respectively, mainly composed of glucans ( $91 \mathrm{~mol} \%$ for IY and $92 \mathrm{~mol} \%$ for BSY). The presence of mannose residues in FR ( $6 \mathrm{~mol} \%$ for IY and $4 \mathrm{~mol} \%$ for BSY), and the carbohydrate 
content of $51 \%$ for IY and $68 \%$ for BSY, indicate the presence of insoluble mannoproteins even after extensive alkali extractions. The oxidation of BSY FR with chlorite and extraction with $1 \mathrm{M} \mathrm{KOH}$ led to the solubilisation of mannoproteins with a low carbohydrate moiety and allowing the recovery of a residue very rich in carbohydrates (92\%), with 99 mol\% of glucose (unpublished results). Thus, combining the data from these two works, it is possible to infer that the mannoproteins remaining insoluble after alkali extraction should have a higher protein than carbohydrate moiety, which is in accordance with the existence of $O$-mannoproteins in the yeast inner cell wall. The presence of mannoproteins in the yeast inner cell wall of Saccharomyces cerevisiae was reported by Moukadiri, Armero, Abad, Sentandreu and Zueco (1997) and Valentin, Herrero, Rico, Miragall \& Sentandreu (1987) ENREF 23.

The alkali extractions led to the solubilization of $46 \%$ of IY and $66 \%$ of BSY, respectively, of mannoproteins present in the AIR. However, the final residues only contained $5 \%$ of IY and $8 \%$ BSY of the AIR mannoproteins. These figures allow to hypothesise that $48 \%$ of the IY AIR mannoproteins and $27 \%$ of BSY ones should have been lost during the dialysis process. Since the IY mannoproteins are less branched and have lower molecular weight than those of BSY, this could explain the higher percentage of loss during dialyses. Regarding the AIR glucans, $76 \%$ of IY and $84 \%$ of BSY remained insoluble in the FR, which is in accordance with the low yield of glucans extracted by the sequential extraction (16 mol\% for IY and $9 \mathrm{~mol} \%$ for BSY). These results are in accordance with Pinto et al. (2015), where only 9\% more of BSY glucans were solubilized with alkali extractions until $8 \mathrm{M} \mathrm{KOH}$.

The glucans present in FR have higher proportion of $(1 \rightarrow 3)$ - than $(1 \rightarrow 6)$-Glc either for IY (41.8 mol\% and $11.3 \mathrm{~mol} \%$, respectively) and for BSY (17.3 mol\% and 9.3 mol\%), which should correspond to $(\beta 1 \rightarrow 3)$ and $(\beta 1 \rightarrow 6)$ glucans (Klis et al., 2006; 
FR $(42.7 \mathrm{~mol} \%)$ than in IY FR (15.9 mol\%), which seems to reveal a change in yeast' polysaccharides composition and structure along the brewery fermentative process.

\subsection{Anomeric configuration of final residues $(1 \rightarrow 4)$-Glc linkages}

In order to identify the anomeric configuration of the $(1 \rightarrow 4)$-linked Glc yeasts FRs, the samples were enzymatically treated with $\alpha$-amylase and cellulase. With the treatment with $\alpha$-amylase, the relative amount of $(1 \rightarrow 4)$-Glc in IY FR decreased from $15.9 \mathrm{~mol} \%$ to $5.3 \mathrm{~mol} \%$. Also, the treatment of IY FR with cellulase allowed to show a decrease in $(1 \rightarrow 4)$-Glc, from $15.9 \mathrm{~mol} \%$ to $11.0 \mathrm{~mol} \%$. Taking into account to extent of these two reactions, it can be inferred that $67 \mathrm{~mol} \%$ of IY FR $(1 \rightarrow 4)$-Glc linkages were $(\alpha 1 \rightarrow 4)$-linked and $31 \mathrm{~mol} \%$ were $(\beta 1 \rightarrow 4)$-linked. Also, the hydrolysis of BSY FR with $\alpha$-amylase and cellulase led to a decrease from $42.7 \mathrm{~mol} \%(1 \rightarrow 4)$-Glc to $17 \mathrm{~mol} \%$ and $29.3 \mathrm{~mol} \%$, respectively. These results showed that $60 \mathrm{~mol} \%$ of $(1 \rightarrow 4)$-Glc linkages were $(\alpha 1 \rightarrow 4)$-linked and $13 \mathrm{~mol} \%$ were $(\beta 1 \rightarrow 4)$-linked. As $27 \%$ of $(1 \rightarrow 4)$-linkages, even after repetition of the hydrolysis, were not cleaved it was not possible to identify their anomeric configuration. The results herein obtained for enzymatic hydrolysis of BSY FR were in agreement with Pinto et al. (2015) when reporting the occurrence of 55 mol $\%$ of $(\alpha 1 \rightarrow 4)$-linked and $30 \mathrm{~mol} \%$ of $(\beta 1 \rightarrow 4)$-linked glucose residues for BSY FR.

These results show that $S$. pastorianus seems to modify the cell wall composition during the brewing process increasing in same proportion both $(\alpha 1 \rightarrow 4)-$ and $(\beta 1 \rightarrow 4)$-Glc residues (Fig. 3), as decreasing the $(1 \rightarrow 3)$-Glc residues (Table 2).

As the glycogen content of yeast cell wall depends on the nutritional state of the cells, the isolation method, and the growth phase, it is possible that the BSY have higher glycogen content due to the stress conferred by the brewing process, which is essential to the osmotic tolerance of yeast during the recycle of yeasts between the fermentative process (Lillie \& Pringle, 1980). The yeast cell wall glycogen exponentially increases 3 

dissolution of the cell wall.

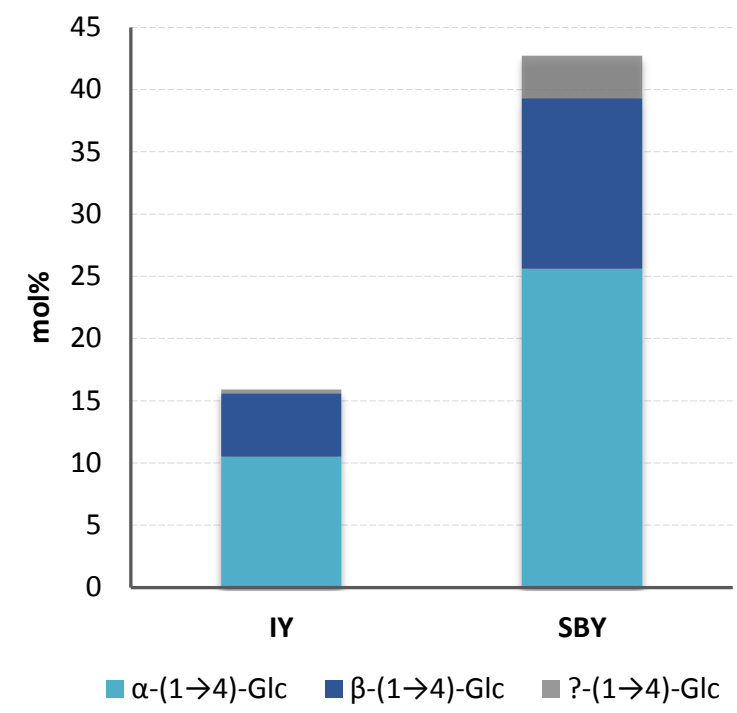

Fig. 3: Molar percentage of $(\alpha 1 \rightarrow 4)$-Glc and $(\beta 1 \rightarrow 4)$-Glc of IY and BSY in relation to total carbohydrates in the FR. The ?-(1 $\rightarrow 4)-$ Glc represents the relative amount of not identified anomeric configuration.

\subsection{Scanning electron microscopy of IY and BSY final residue}

Figure 4 shows the SEM images of IY FR (Fig. 4a and 4c) and BSY FR (Fig. 4b and 4d) after the sequential extraction, revealing that the brewer's yeast cells original structure was preserved in FR. The preservation of yeast structure and shape by glucans after removal of outer layer of mannoproteins has been already reported for the spent yeast S. cerevisiae (Liu, Wang, Cui \& Liu, 2008). However, the cell wall structure was completely destroyed after enzymatic hydrolysis with $\alpha$-amylase and cellulase for IY FR (Fig 4e) and BSY FR (Fig 4f), showing that $\alpha$ and $\beta(1 \rightarrow 4)$-Glc linkages are important for preservation of the cell wall integrity, maintaining the network of glucans and possibly the inner layer mannoproteins. This is supported by the observations of 

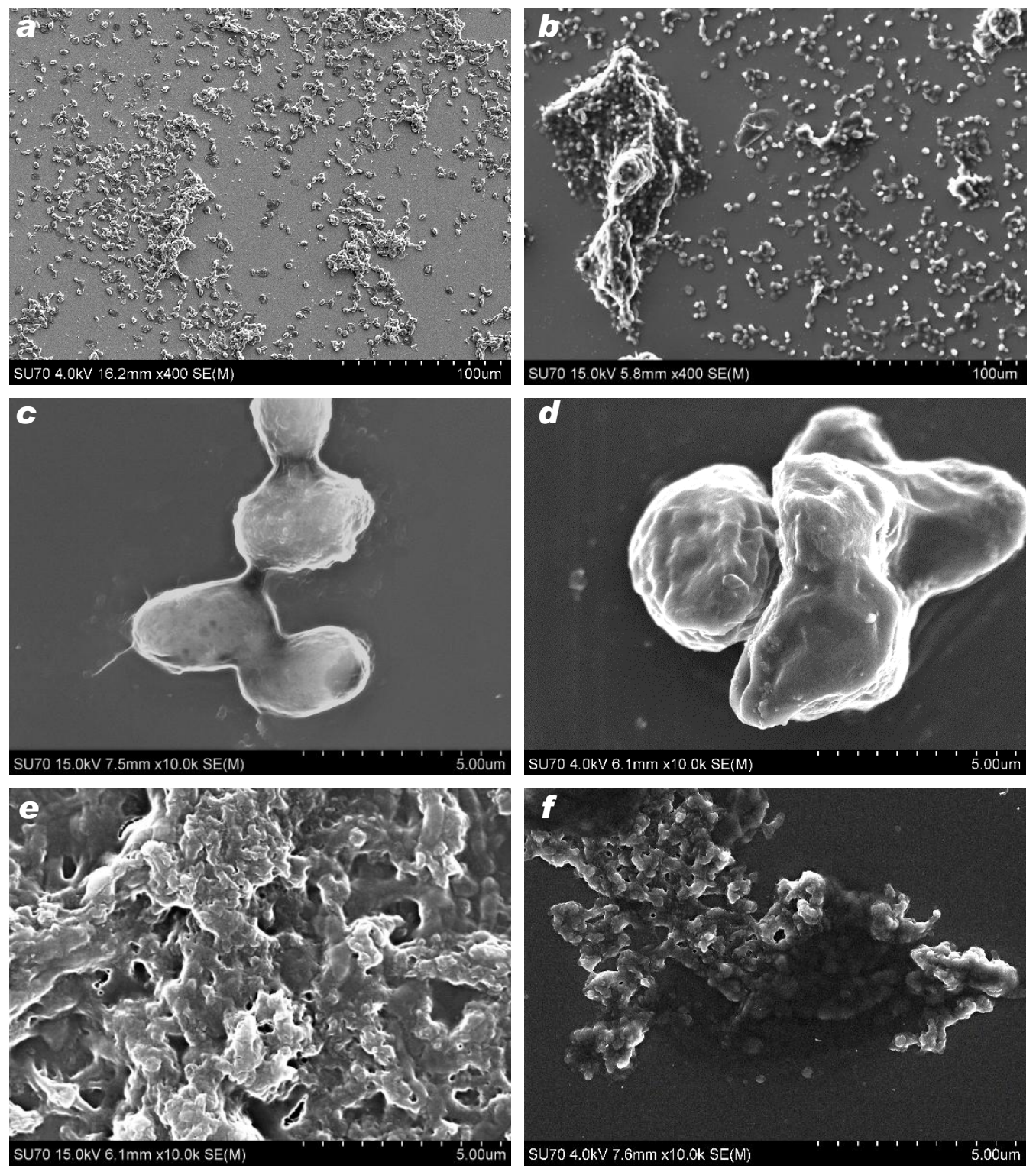

Fig. 4: Scanning electron microscopy (SEM) images of a) IY FR with 400 $\times$ of magnification and c) with $10,000 \times$ of magnification; b) BSY FR with $400 \times$ of magnification and d) with $10,000 \times$ of magnification; enzymatic hydrolysed residues e) IY FR with $10,000 \times$ of magnification and f) BSY FR with $10,000 \times$ of magnification.

\section{Conclusions}

The results of this work show that BSY polysaccharides have different features

374 from those of IY. This was shown in the mannoproteins extracted with hot water and alkali solutions, where higher branched and phosphorylated polymers were observed for 
376 BSY. The modifications of $S$. pastorianus mannoproteins with the brewing process

377 could be important since they could led to an increase of yeast flocculation and an 378 increase of negative charge of yeast surface, important to yeast protection against 379 osmotic stress, lytic enzymes and preservation of yeast viability.

380 Contrarily to mannoproteins, the glucans of $S$. pastorianus were poorly extracted 381 from both IY and BSY cell walls. IY glucans were mainly composed by $(1 \rightarrow 3)$-Glc 382 residues while the BSY glucans were mainly composed by $(1 \rightarrow 4)$-Glc linkages. 383 Although with different $(1 \rightarrow 4)$-Glc content between IY and BSY, both had 1/3 of $384(\beta 1 \rightarrow 4)$ and $2 / 3$ of $(\alpha 1 \rightarrow 4)$-linked glucose. These results showed that $S$. pastorianus seems changing their glucans during the brewing process, incrementing in the same proportion the content of $(\alpha 1 \rightarrow 4)$ and $(\beta 1 \rightarrow 4)$-Glc over the content of $(1 \rightarrow 3)$-Glc linkages. The higher proportion of both $(1 \rightarrow 4)$-Glc anomeric configurations in BSY could result from adaptation of $S$. pastorianus to fermentative stress, since glycogen is important to yeast osmotolerance and cellulose-like structures could be important to increases cell wall strength.

Other important feature observed for $S$. pastorianus was the preservation of the three-dimensional structure of the yeast after the sequential polysaccharides extraction. The yeast final residue seems to form a hollow structure that was only destroyed after enzymatic hydrolysis of its $(1 \rightarrow 4)$-Glc linkages. This allows to infer that these linkages are important for maintenance of the yeast structure. The observation of the existence of these capsules and how they can be formed could open new perspectives for yeast valuation. 
399

400

401

402

403

404

405

406

407

408

409

410

411

412

413

414

415

416

417

418

419

420

421

422

423

424

425

426

427

428

429

430

431

432

The authors gratefully acknowledge FCT for the financial support of the Research Unit 62/94-QOPNA (project PEst-C/QUI/UI0062/2013; FCOMP-01-0124-FEDER-037296) and the post-doctoral grant SFRH/BPD/70589/2010 of Elisabete Coelho. Authors also thank Tiago Brandão from Unicer Bebidas, SA for the yeasts supply, Paula Santos (CICECO - University of Aveiro) for the solid state NMR analysis, Ricardo J. B. Pinto and Carmen S. R. Freire for the SEM images.

\section{References}

Arvindekar, A. U., \& Patil, N. B. (2002). Glycogen — a covalently linked component of the cell wall in Saccharomyces cerevisiae. Yeast, 19, 131-139.

Blakeney, A. B., Harris, P. J., Henry, R. J., \& Stone, B. A. (1983). A simple and rapid preparation of alditol acetates for monosaccharide analysis. Carbohydrate Research, 113, 291-299.

Blumenkrantz, N., \& Asboe-Hansen, G. (1973). New method for quantitative determination of uronic acids. Analytical Biochemistry, 54, 484-489.

Ciucanu, I., \& Kerek, F. (1984). A simple and rapid method for the permethylation of carbohydrates. Carbohydrate Research, 131, 209-217.

Corbacho, I., Olivero, I., \& Hernández, L. M. (2005). A genome-wide screen for Saccharomyces cerevisiae nonessential genes involved in mannosyl phosphate transfer to mannoprotein-linked oligosaccharides. Fungal Genetics and Biology, 42, 773-790.

Dake, M. S., Khetmalas, M. B., \& Amarapurkar, S. V. (2011). Role of insoluble glycogen in ethanol adaptation mechanism of Saccharomyces italicus. Indian Journal of Science and Technology, 4, 52-55.

Dengis, P. B., Nelissen, L. R., \& Rouxhet, P. G. (1995). Mechanisms of yeast flocculation: comparison of top- and bottom-fermenting strains. Applied and Environmental Microbiology, 61, 718-728.

Gibson, B. R., Lawrence, S. J., Leclaire, J. P. R., Powell, C. D., \& Smart, K. A. (2007). Yeast responses to stresses associated with industrial brewery handling. FEMS Microbiology Reviews, 31, 535-569.

Jadhav, J. P., Dake, M. S., \& Patil, N. B. (2008). $\alpha, \beta$-glucan complex in Saccharomyces carlsbergenesis. Asian Journal of Chemistry, 20, 55-65.

Jigami, Y., \& Odani, T. (1999). Mannosylphosphate transfer to yeast mannan. Biochimica et Biophysica Acta (BBA) - General Subjects, 1426, 335-345.

Klis, F. M., Boorsma, A., \& De Groot, P. W. J. (2006). Cell wall construction in Saccharomyces cerevisiae. Yeast, 23, 185-202. 
Klis, F. M., Mol, P., Hellingwerf, K., \& Brul, S. (2002). Dynamics of cell wall structure in Saccharomyces cerevisiae. FEMS Microbiology Reviews, 26, 239-256.

Kwiatkowski, S., Thielen, U., Glenney, P., \& Moran, C. (2009). A study of Saccharomyces cerevisiae cell wall glucans. Journal of the Institute of Brewing, 115, 151-158.

Lesage, G., \& Bussey, H. (2006). Cell wall assembly in Saccharomyces cerevisiae. Microbiology and Molecular Biology Reviews, 70, 317-343.

Lillie, S. H., \& Pringle, J. R. (1980). Reserve carbohydrate metabolism in Saccharomyces cerevisiae: responses to nutrient limitation. Journal of Bacteriology, 143, 1384-1394.

Liu, D., Zeng, X.-A., Sun, D.-W., \& Han, Z. (2013). Disruption and protein release by ultrasonication of yeast cells. Innovative Food Science \& Emerging Technologies, 18, 132-137.

Liu, X.-Y., Wang, Q., Cui, S. W., \& Liu, H.-Z. (2008). A new isolation method of $\beta$-Dglucans from spent yeast Saccharomyces cerevisiae. Food Hydrocolloids, 22, 239-247.

Moukadiri, I., Armero, J., Abad, A., Sentandreu, R., \& Zueco, J. (1997). Identification of a mannoprotein present in the inner layer of the cell wall of Saccharomyces cerevisiae. Journal of Bacteriology, 179, 2154-2162.

Nunes, F. M., \& Coimbra, M. A. (2002). Chemical characterization of the highmolecular-weight material extracted with hot water from green and roasted robusta coffees as affected by the degree of roast. Journal of Agricultural and Food Chemistry, 50, 7046-7052.

Pinto, M., Coelho, E., Nunes, A., Brandão, T., \& Coimbra, M. A. (2015). Valuation of brewers spent yeast polysaccharides: A structural characterization approach. Carbohydrate Polymers, 116, 215-222.

Quirós, M., Morales, P., Pérez-Través, L., Barcenilla, J. M., \& Gonzalez, R. (2011). A new methodology to determine cell wall mannoprotein content and release in wine yeasts. Food Chemistry, 125, 760-766.

Rainieri, S., Kodama, Y., Kaneko, Y., Mikata, K., Nakao, Y., \& Ashikari, T. (2006). Pure and mixed genetic lines of Saccharomyces bayanus and Saccharomyces pastorianus and their contribution to the lager brewing strain genome. Applied and Environmental Microbiology, 72, 3968-3974.

Ruiz-Herrera, J., Leon, C. G., Carabez-Trejo, A., \& Reyes-Salinas, E. (1996). Structure and chemical composition of the cell walls from the haploid yeast and mycelial forms of Ustilago maydis. Fungal Genetics and Biology, 20, 133-142.

Sang, Y., Prakash, O., \& Seib, P. A. (2007). Characterization of phosphorylated crosslinked resistant starch by $31 \mathrm{P}$ nuclear magnetic resonance $\left({ }^{31} \mathrm{P}\right.$ NMR) spectroscopy. Carbohydrate Polymers, 67, 201-212.

Selvendran, R. R., March, J. F., \& Ring, S. G. (1979). Determination of aldoses and uronic acid content of vegetable fiber. Analytical Biochemistry, 96, 282-292.

Smart, K. (2009). Expression of the cell wall mannoprotein genes CWP and DAN during industrial-scale lager fermentations. Journal of the American Society of Brewing Chemists, 67, 58-62. 
476 Soares, E. V. (2011). Flocculation in Saccharomyces cerevisiae: a review. Journal of 477 Applied Microbiology, 110, 1-18.

478 Sousa, A. F., Matos, M., Pinto, R. J. B., Freire, C. S. R., \& Silvestre, A. J. D. (2014). 479 One-pot synthesis of biofoams from castor oil and cellulose microfibers for energy 480 absorption impact materials. Cellulose, 21, 1723-1733.

481 Tamai, Y., Momma, T., Yoshimoto, H., \& Kaneko, Y. (1998). Co-existence of two 482 types of chromosome in the bottom fermenting yeast, Saccharomyces pastorianus. 483 Yeast, 14, 923-933.

484 Valentin, E., Herrero, E., Rico, H., Miragall, F., \& Sentandreu, R. (1987). Cell wall 485 mannoproteins during the population growth phases in Saccharomyces cerevisiae. 486 Archives of Microbiology, 148, 88-94.

487 Zhang, L., Jin, Y., Xie, Y., Wu, X., \& Wu, T. (2014). Releasing polysaccharide and 488 protein from yeast cells by ultrasound: Selectivity and effects of processing parameters. 489 Ultrasonics Sonochemistry, 21, 576-581.

490 


\section{- Graphical Abstract}

\section{Saccharomyces pastorianus}

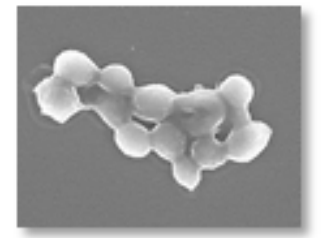

IY - Inoculum Yeast

BSY - Brewers Spent Yeast

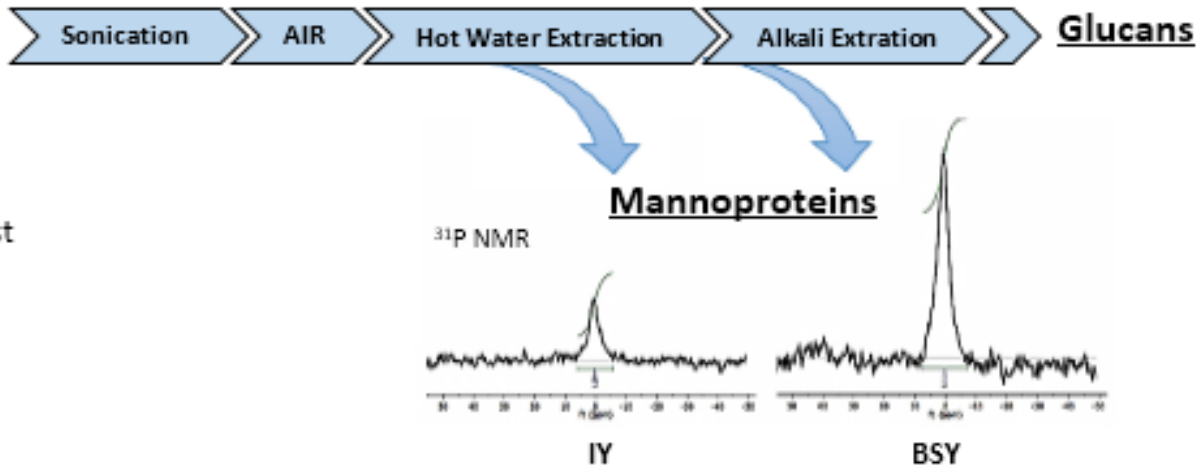

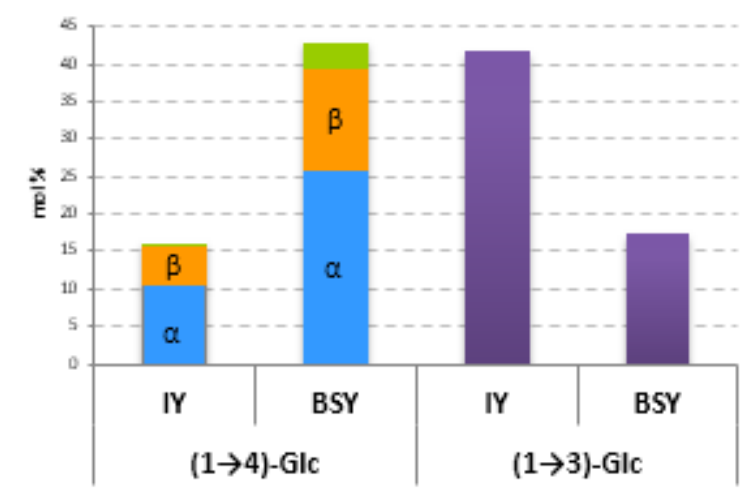

